\title{
The Deuteronomic view of history in Second Temple Judaism
}

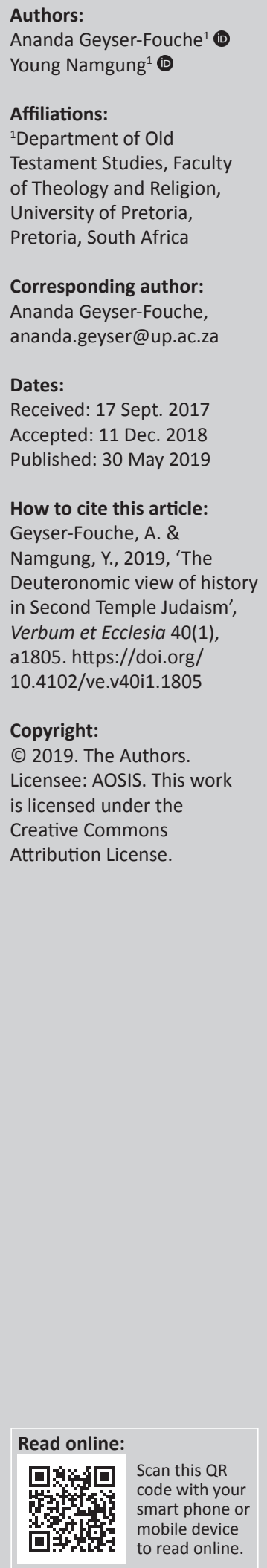

Authors:

Affiliations:

${ }^{1}$ Department of Old stament Studies, Faculty University of Pretoria, Pretoria, South Africa

Corresponding author: Ananda Geyser-Fouche,

Dates:

Received: 17 Sept. 2017 Accepted: 11 Dec. 2018

How to cite this article: Geyser-Fouche, A. \& Namgung, Y., 2019, 'The in Second Temple Judaism', Verbum et Ecclesia 40(1), 1805. https://doi.org/ Copyright: Licensee: AOSIS. This work is licensed under the Creative Commons Attribution License.
The Babylonian Exile was a historical catalyst compelling Jewish authors of the Second Temple period to deal with their respective situations in the course of history according to or against - various predicaments from which they suffered in an unprecedented manner. Second Temple Jews were faced with the most fundamental uneasiness: it seemed that God abandoned his people owing to their breaking of the covenant. Therefore, it was important to reconceptualise their worldview into which creation, history, and covenant could be incorporated and which could vouchsafe the ongoing relationship with God to their respective situations.

Intradisciplinary and/or interdisciplinary implications: In this article, the worldview of Second Temple Judaism is reflected on by observing how different communities in Second Temple Judaism engaged the Song of Moses in Deuteronomy 31-32. This article focusses on the interpretations of this passage in Second Temple Judaism, with specific reference to selected texts from Qumran, Tobit, the Testament of Moses, Philo, Josephus and Sifre Deuteronomy. Implicated disciplines are Old Testament studies, Apocryphal studies, Dead Sea Scroll studies and New Testament studies.

Keywords: Second Temple Judaism; exile; worldview; the Deuteronomic view of history; Qumran; Tobit; Song of Moses; Testament of Moses; Philo; Josephus; Sifre Deuteronomy.

\section{Introduction}

Since the Babylonian Exile, Jewish authors of the Second Temple period (515 BCE-70 CE) attempted to make sense of their respective situations in the course of history according to - or against - various predicaments from which they suffered in an unprecedented manner. The most fundamental issue was that the Second Temple Jews believed that their God abandoned his people owing to their breaking of his covenant. In other words, they experienced feelings of despondency in their respective situations resulting from the perception that the covenant God was no longer functional and relevant. Therefore, it was most important to reconceptualise their worldview, into which creation, history and covenant were incorporated and which would vouchsafe the ongoing relationship with God in their respective situations. In doing so, Jewish authors of the Second Temple period could manage to militate against such despondency. The thesis of this study is that Deuteronomy 31-32 could furnish a framework of history in the Second Temple period. This study thus aims to make clear in what sense and to what extent the Song of Moses would play a constitutive role in establishing the hermeneutics of history in Second Temple Judaism.

\section{Deuteronomy 31-32 as a framework for historical reconstruction}

Crawford (2005:127) observes, '[t]he book of Deuteronomy was one of the most popular religious texts in the Second Temple period'. It is for this reason that it is necessary to deal succinctly with the theology of Deuteronomy 31-32 in its canonical context and then continue to sketch how Jewish authors of the Second Temple period, in varying degrees, adapted and adopted the theology of Deuteronomy 31-32 in their writings - albeit in a cursory manner.

The Song of Moses (hereafter the Song) in Deuteronomy 32, along with the narrative section in Deuteronomy 31 (as an introduction to the Song), 'constitutes a poetic summary of Israel's history of apostasy, punishment and grace' (Braulik 1994:100). Nonetheless, the theology of Deuteronomy 31-32 is more than that, as Israel's history of apostasy, punishment and grace serves to shed more light on the faithfulness of God attested in his dealings with Israel in the course of its history. 
It becomes clear when we deal with the genre of Deuteronomy 31-32. When it comes to the genre of the Song, there are two scholarly viewpoints: (1) one group views the Song as a 'covenant lawsuit' or rîb; (2) the other views it as wisdom literature (Thiessen 2004). It is for this reason that Thiessen insists that the Song may owe its existence to a liturgy. He goes on to say (Thiessen 2004) that:

the Song was meant to prescribe the people's reaction, both to guard them from acting like the sinful generation of the Song and to lead them in responding to any evil that was brought upon it. (p. 424)

Weitzman (1994) attempts to interpret the Song in terms of its narrative setting, which appears to be in tandem with that of the Word of Ahiqar. ${ }^{1}$ He insists (Weitzman 1994) that:

[t]he combination of didactic and legal elements within the proverbs of Ahiqar thus serves the logic of the surrounding narrative, which calls for the sage to issue a final teaching that is at once instructional and incriminatory. (p. 391)

He comes to the conclusion that the Song should be understood as 'Moses' final teaching to the thankless children of Israel' (Weitzman 1994:393). By focussing on the term עy [witness] and its cognate, Britt (2004) considers the Song as 'a textual witness'. He goes on to say (Britt 2004) that:

[t]he notion of Deuteronomy 31-32 as a textual witness or memorial helps resolve the paradox that the general meaning of the narrative is clear but that the details of narration, chronology, and focus are confusing. (p. 141)

In other words, the Song should be understood as didactic and timeless. Despite that there are two scholarly viewpoints concerning the genre of the Song, it stands to reason that they have some commonalities. One may thus argue that the theology of the Song is both didactic and timeless.

The Song is concerned with the relationship between God and his elected people, Israel. It deals with 'a meditation on divine justice in history' in a didactic and timeless manner. In doing so, 'a character portrait of $\mathrm{YHWH}^{\prime}$ comes to the forefront in the Song (Britt 2004:148). Britt (2004) is of the opinion that:

[w]ithin its canonical context it represents a canonical mise en abyme, or a condensed statement of the covenant relationship between $\mathrm{YHWH}$ and Israel rendered ... not historically but rather in developmental and structural terms. (p. 158)

It becomes clear when we look at the content of the Song in terms of the faithfulness of God to his elected people, Israel. In this regard, the Song best represents the Deuteronomic view of Israel's history. This is known as the sinjudgement-restoration pattern running not only through Deuteronomy but also through all books influenced by this tradition (e.g. the Book of the Twelve ${ }^{2}$ ). Such a pattern is also

1.Weitzman (1994:389) also points out significant differences between the two narratives: '[t] the literary evidence offers no asy way to overcome these differences, and they seriously complicate the relationship of Ahiqar to Deuteronomy $31^{\prime}$.

2.For the sin-judgement-restoration pattern in the Book of the Twelve, see House (1990). adopted by other Jewish authors of the Second Temple period (Abasciano 2005:143; cf. Hays 1989:163-164). ${ }^{3}$ Aside from the Song in Deuteronomy 31-32, the narrative of Deuteronomy 27-30 may also serve as evidence of the deuteronomistic scheme of history or the SER pattern (Sin-Exile-Return) (Morland 1995:33, italics in the original).

Given that Deuteronomy 31-32 furnished a framework of history in the Second Temple period, I now turn to how other Jewish authors of Second Temple Judaism used Deuteronomy 31-32 as a framework of history in their respective contexts in order to find meaning in their contexts.

\section{Song of Moses in Second Temple Judaism}

The survey that follows is not exhaustive, but hopefully representative of how authors used the Song. It is fair to say that it will be conducive to show to what extent and in what manner Jewish authors of the Second Temple period adapted and adopted the Song in their theologising when managing their respective situations.

\section{Qumran literature ${ }^{4}$}

The Song is given 'special attention within the Qumran community' (Waters 2006:48). The Song, which contains 'its denunciation of Israel's apostasy', has an influence on the Qumran community (Bell 1994:217). Firstly, Deuteronomy 32:28 is alluded to in CD 5:17 (i.e. the Damascus Document).

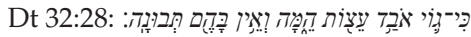

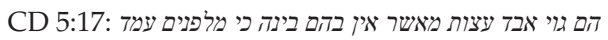

Dt 32:28: 'For they are a nation lacking in counsel, and there is no understanding in them'.

CD 5:17: they are folk bereft of advice, in that there is no intelligence in them. For in ancient times there arose

It is of interest to note that, in the original context of Deuteronomy 32, it appears to be ambiguous whether the referent in Deuteronomy 32:28 is Israel's enemy or apostate Israel (cf. Mayes 1981:389-390). While he views Israel's enemy, namely the no-nation, as the primary referent, Nelson (2004:375) does not dismiss the possibility of the referent being apostate Israel. Craigie (1976:36) prefers to view Israel as its referent in that Israel's lack of discernment acts as a cause of God's punishment in its foregoing verses. What is clear in CD 5:17, however, is the fact that the referent appears to be 'an apostate group within Israel' (Bell 1994:218; e.g. Jannes and Jambres in CD 5:17-19). Nonetheless, it is worth noting that CD 5:17-19 goes beyond identifying such an apostate group to be foolish and unintelligent. Lange (1997:417-418) points to the fact that 'CD 5:17-19 does not simply use Jannes and Jambres as a paradigm for Israelite apostasy but as an example of how Belial leads Israel astray'.

3.However, Abasciano 2005$)$ attempts to put more weight on Exodus $32-34$ than on Deuteronomy 32 with regard to the Deuteronomic view of Israel's history reflected in Romans 9-11.

4.If not noted otherwise, the translation of García Martínez and Tigchelaar is used for the Qumran texts. 
CD 5:17-19: they are folk bereft of advice, in that there is no intelligence in them. For in ancient times there arose (18) Moses and Aaron, by the hand of the prince of lights and Belial, with his cunning, raised up Jannes and (19) his brother during the first deliverance of Israel.

Briefly put, the immediate context of CD 5:17-19, in which Deuteronomy 32:28 is alluded to in the beginning, illustrates that it is tinged by the influence of the Treatise on the Two Spirits (1QS 3:13 - 4:26 [i.e. the Community Rule]). Hence, Lange (1997:419) is correct in saying that 'apostasy is viewed as being caused by an attack of the servants of the spirit of darkness (see 1QS 3:21-24)'.

Secondly, it is possible that Deuteronomy 32:33 may be alluded to twice in $1 \mathrm{QH}^{\mathrm{a}}$ 13:10 (i.e. the Hodayot) and 13:27 (Suk 5:10 and 5:27; DJD 40. 13:10 and 13:27): ${ }^{5}$

Dt 32:22: 'Their wine is the venom of serpents, And the deadly poison of cobras'.

$1 \mathrm{QH}^{\mathrm{a}}$ 13:10: teeth are like a sword, whose fangs are like a sharpened spear. Vipers' venom is all their scheming to snatch away. They lay in wait, but did not

$1 \mathrm{QH}^{\mathrm{a}}$ 13:27: a lying tongue, like vipers' venom that spreads to the extremities, like crawlers in the dust they shoot to gra[b, serpents' [poison]

The immediate context of $1 \mathrm{QH}^{\mathrm{a}} 13$ is also similar to $\mathrm{CD}$ 5:17-19 in that '[t]he Hodayot mentions Belial's torrents $\left(1 \mathrm{QH}^{\mathrm{a}} 3: 31\right)$ and contains a thanksgiving to God, who had protected from such, venom included $\left(1 \mathrm{QH}^{\mathrm{a}} 5: 10,27\right)^{\prime}$ (Uusimäki 2016:130). ${ }^{6}$ Moreover, the referent of $1 \mathrm{QH}^{\mathrm{a}} 13$ is also 'the Jewish enemies of the writer' (Bell 1994:219). However, it is more probable that Jeremiah $16: 16$ is alluded to in $1 \mathrm{QH}^{\mathrm{a}}$ 13:10 and 13:27 (cf. Lange 2012). ${ }^{7}$ Notwithstanding this, it is fair to say that the phrases of Deuteronomy 32 can be used to deal with the scheme of Belial in the Qumran community.

Thirdly, Deuteronomy 32:22 is alluded to twice in $1 \mathrm{QH}^{\mathrm{a}} 11: 31$ (Suk. 3:31; DJD 40. 11:32) and 4:13 (Suk. 17:13; DJD 40. 4:25):

Dt 32:22: For a fire is kindled in My anger, And burns to the lowest part of Sheol, And consumes the earth with its yield, And sets on fire the foundations of the mountains.

$1 \mathrm{QH}^{\mathrm{a}}$ 11:31: and the tract of dry land; the bases of the mountains does he burn and converts the roots of flint rock into streams of lava. It consumes right to the great deep [...]

$1 \mathrm{QH}^{\mathrm{a}}$ 4:13: [Even though you burn] the foundations of mountains and fire [sears] the base of Sheol, those who ... in your regulations.

As with Deuteronomy 32 in $1 \mathrm{QH}^{\mathrm{a}} 13,1 \mathrm{QH}^{\mathrm{a}} 11$, in which Deuteronomy 32:22 is alluded to in $1 \mathrm{QH}^{\mathrm{a}} 13: 31$, revolves

$5.1 \mathrm{QH}^{\mathrm{a}}$ has the three different numbering systems available at present. This study follows the text and numbering of García Martínez and Tigchelaar, but we will also present the other two in parenthesis; they are Sukenik's (Suk) and the one adapted in Discoveries in the Judean Desert series (DJD).

6.Uusimäki follows Sukenik's text.

7.The textual relationship between Deuteronomy 32 and Jeremiah goes beyond the scope of this study. For a discussion of this relationship, see Lundbom (2013:38). around the scheme of Belial. It is worth noting that Sheol imagery in $1 \mathrm{QH}^{\mathrm{a}}$ 4:13 illustrates that Jewish theologians in the Second Temple period would make use of Deuteronomy 32:22 in their attempts to make sense of 'an eschatological destruction' (Uusimäki 2016:182). ${ }^{8}$ Deuteronomy 32:22 is used to refer to 'God judging the wicked of Israel and yet saving a remnant' in the Qumran community (Bell 1994:220).

Fourthly, Deuteronomy 32:42 is alluded to twice in 1QM 12:11-12 and 19:4 (i.e. the War Scroll):

Dt 32:42: I will make My arrows drunk with blood, And My sword shall devour flesh, With the blood of the slain and the captives, From the long-haired leaders of the enemy.

1QM 12:11-12: collect your spoil, Performer of Valiance! Place your hand on the neck of your enemies and your foot on the piles of slain! Strike the peoples, your foes, and may your sword (12) consume guilty flesh! Fill your land with glory and your inheritance with blessing: may herds of flocks be in your fields / silver/gold, and precious stones.

1QM 19:4: [of the dead! Strike the peoples, your foes,] and may your sword consume flesh! Fill your land with glory and your inheritance with blessing: [may herds]

Most scholars view Israel's enemy as the referent of God's vengeance in Deuteronomy 32:42. However, the possibility that it refers to apostate Israel remains. Notwithstanding this, it is clear that the referent in 1QM 12:11-12 and 19:4 includes apostate Israel among the enemies of the writer who will experience God's vengeance (Bell 1994; Uusimäki 2016; e.g. the violators of the covenant in 1QM 1:2).

In summary, it is made clear that the Song, or at least some of its phrases, plays an important role in substantiating the theologoumena of the Qumran community (Bell 1994:221). From the vantage point of the Yahad (i.e. the Covenant Community of Qumran) as the elected community, the Qumran covenanters attempted to translate the theology of the Song into the dualism or dualistic ways of thinking of the Qumran community.

\section{Tobit}

Weitzman (1997:67) points out that 'Tobit's "prayer of rejoicing" in Tobit 13 alludes to the Song of Moses in Deuteronomy 32'. According to Weitzman (1997:67), 'Raphael's farewell exhortation to Tobit and his son Tobias' in Tobit 12:6-15 appears to resonate with an 'instruction given to Moses and Joshua by God' in Deuteronomy 31:14-30. When it comes to the songs in Tobit 13 and Deuteronomy 32, these two songs have in common the fact that (1) the songs are rendered by sages before their death, (2) an address from sages to the survivors ensues after the song (e.g. Deuteronomy 33 and Tobit 14) and (3) similar language is employed in both the songs (Weitzman 1997:67). Thus, it is likely that Tobit in Tobit $12-13$ can be regarded as the second Moses who follows the trails of the Mosaic tradition in Deuteronomy 31-32. Regarding such similarities, linguistic or conceptual, between 8.For example, "the Sheol of Abaddon' in $1 \mathrm{OH}^{\mathrm{a}} 11 \mathrm{1}: 19.1 \mathrm{QH}^{\mathrm{a}} 11$ is also concerned with eschatological destruction. 
Tobit 12-13 and Deuteronomy 31-32, Bauckham's (2006) observation is worth citing in full:

[I]t is not because the latter [= the Song of Moses] ends with Moses' prediction of Israel's original settlement in the land, whereas Tobit's foresees the corresponding re-settlement of exiled Israel in the land, but because the Song of Moses was widely understood as itself predicting Israel's restoration after [the] exile. (p. 142)

It is interesting to note that Tobit's pilgrimage during his exile acts as a beacon for Israel's destiny. Tobit's pilgrimage during his exile reaches its climax in Tobit 13 . Tobit 13 can be divided into two subsections: Tobit 13:1-8 and Tobit 13:9-18 (cf. Fitzmyer 2003:304). The exhortation/invocation of Tobit in Tobit 13:1-8 revolves around the praise of God, a call to repentance and the hope of restoration. The description of Israel's future in Tobit 13:9-18 corresponds to the pattern of the Mosaic tradition in the Song (i.e. settlement in the Promised Land; Israel's apostasy; God's punishment; ultimate restoration). Hence, Moore (1996:284, italics original) is correct in saying that '[i]f God had done all that for Tobit and his family, how much more, concludes Tobit, will God do for his people and his Holy City?' God's faithfulness and sovereignty demonstrated in Tobit's pilgrimage during his exile give rise to the hope of Israel's future. Tobit's song in Tobit 13:1-2, which is a paraphrasing of Deuteronomy 32:39, shows it clearly:

Dt 32:39: 'See now that I, I am He, and there is no god besides $\mathrm{Me}$; It is I who put to death and give life. I have wounded, and it is I who heal; and there is no one who can deliver from My hand'.

Then Tobit wrote a prayer of rejoicing, and said: 'Blessed is God who lives for ever, and blessed is his kingdom. For he afflicts, and he shows mercy; he leads down to Hades, and brings up again, and there is no one who can escape his hand...' (Tob 13:1-2 RSV $\left.{ }^{9}\right)$

Then, it is clear that Tobit's lamentation in Tobit 3:4, which bears the curses of Deuteronomy 28, will be finally revoked. ${ }^{10}$ Tobit lamented:

For they disobeyed thy commandments, and thou gavest us over to plunder, captivity, and death; thou madest us a byword of reproach in all the nations among which we have been dispersed. (Tob 3:4 RSV)

In summary, by way of evoking the Song linguistically and conceptually, Tobit would attempt to bring out the hope of Israel's future convincingly in that 'the divinely woven patterns of Israel's past continue into Israel's exilic present' (Weitzman 1997:70).

\section{Testament of Moses}

The Testament of Moses (circa the first century CE; hereafter T. Moses) can be regarded as a retelling of Deuteronomy 31-34. Priest (1983:923) points out that T. Moses appears to 9.Revised Standard Version (RSV)

10.For the allusion of Deuteronomy 30:1-10 in Tobit 13:5-6, which is concerned with restoration in terms of the covenantal blessings and curses, see Henderson (2014:151-153). be 'framed around the end of the book of Deuteronomy' 31-34. The Testament of Moses is the 'the farewell exhortation' of Moses to Joshua which predicts Israel's destiny from the entrance into the Promised Land to the end of days (Priest 1983:919). It is worth noting that the Deuteronomic view of Israel's history, namely the sin-judgement-restoration pattern, can be found in T. Moses (cf. Harrington 1973:65; Tromp 1993:124). In other words, T. Moses reflects such a Deuteronomic view of Israel's history in a linguistic and conceptual manner (cf. Crowe 2012:66; Harrington 1973:61). Most interesting to note is the fact that in T. Moses 9-10, Taxo the Levite plays an exemplary role as the righteous martyred in provoking God's vengeance (cf. Licht 1961:98). The narrative flow of T. Moses 9-10 can be demarcated as follows:

An episode that appears to be the culmination of this historical survey tells of the resolve of a Levite and his seven sons to die rather than betray their ancestral faith (9:1-7). There follows an eschatological hymn that portrays the destruction of the evil one at the hands of Israel's guardian angel (10:1-2), cataclysmic cosmic events (10:3-6), and the exaltation of Israel in the end of days (10:7-10). (OTP 1:919) ${ }^{11}$

Tromp (1993:231) points out that 'Taxo will subsequently take revenge on Israel's enemies, a reward which is often expected to be given to the righteous in the eschatological time'. The role of the martyred righteous in provoking God's vengeance is 'a unique teaching' in T. Moses (Priest 1983:923). However, Priest (1983:923) concedes that, despite such a role of Taxo in provoking God's vengeance, 'God alone is the worker of his predetermined will'. When it comes to the perspective of martyrdom in T. Moses, which is different from 1 Maccabees and 2 Maccabees, Gathercole's (2002:58) observation is instructive hereof: '[T]he Assumption of Moses [= Testament of Moses] is predicated on a very strong theology of election' (cf. Priest 1983:923). In this regard, Harrington's (1973) status quaestionis is well pointed when he poses a question:

Was the Testament of Moses written in the way that it was because testaments tend to be predictions of the future, or because Deuteronomy 31-34 leaves itself open to interpretation as a prediction of the future? (p. 66)

He answers then that the latter may be the case.

In summary, T. Moses gives a glimpse of why and how Jewish authors of the Second Temple period adapted and adopted the Song, albeit not isolated from Deuteronomy 31-34, in a form of 'future expansion'12 according to which they could approach their respective situations.

\section{The writings of Philo ${ }^{13}$}

Philo designated the Song as either 'the Great Song' (e.g. Qoud deterius potiori insidari soleat 114) or 'the Greater Song' 11.OTP is an acronym of the Old Testament Pseudepigrapha. 12.Cf. Harrington's (1973) terminology.

13.Philo of Alexandria (20 BCE-50 CE) is a Hellenistic Jewish philosopher living in Alexandria. By using philosophical allegory, he was at pains to harmonise the Torah with Hellenistic philosophies in an apologetical manner. 
(e.g. Legatio ad Gaium 3.105). ${ }^{14}$ He distinguished it from the Song of the Sea in Exodus 15. The Song is alluded to in De virtutibus 72-75.

Having discoursed thus suitably to his subjects and the heir of his headship, he proceeded to hymn God in a song in which he rendered the final thanksgiving of his bodily life for the rare and extraordinary gifts with which he had been blest from his birth to his old age. He convoked a divine assemblage of the elements of all existence and the chiefest parts of the universe, earth and heaven, one the home of the mortals, the other the house of immortals. With these around him he sang his canticles with every kind of harmony and sweet music in the ears of both mankind and ministering angels. (Virt 72-73, LCL) $)^{15}$

It seems that De virtutibus 73 is an allusion of Deuteronomy 32:1: 'Give ear, O heavens, and let me speak; And let the earth hear the words of my mouth' (cf. Weitzman 1997). It is of interest to note that the manner in which Deuteronomy 32:1 is alluded to in De virtutibus 73 sheds more positive light on the Mosaic tradition in Deuteronomy 32 (cf. Bell 1994:225; e.g. 'every kind of harmony and sweet music' is added up to Dt 32:1). This is because, in De virtutibus, Philo dealt with the virtues prescribed in the Law by Moses and introduced the life of Moses as a supreme exemplar of $\varphi \imath \lambda \alpha v \theta \rho \omega \pi i \alpha$ [philanthropy] (cf. Lierman 1976:202; e.g. Virt 51).

Then, in De virtutibus 75, Philo would introduce Israel's past history as God's admonitions for the present occasion:

Thus is his post amid the ethereal choristers the great Revealer blended with the strains of thankfulness to God his own true feelings of affection to the nation, therein joining with his arraignment of them for past sins his admonitions for the present occasion and calls to a sounder mind, and his exhortations for the future expressed in hopeful words of comfort which needs must be followed by their happy fulfilment. (Virt 75, LCL)

The Song in De virtutibus 72-75 bears 'its hortatory character', by which to make sense of 'a judgment about the future' (Lincicum 2010:106). Briefly put, the Song is not used to denote 'future expansion' by Philo as the author of T. Moses did. Philo would not view 'the events of Deut 32 as transpiring in his own day' (Waters 2006:70). It becomes clear when Philo alluded to the Blessing of Moses in Deuteronomy 33 in De vita Mosis.

Then indeed, we find him possessed by the spirit, no longer uttering general truths to the whole nation but prophesying to each tribe in particular the things which were to be and hereafter must come to pass. Some of these have already taken place, others are still looked for, since confidence in the future is assured by fulfilment in the past. (Mos 2.288, LCL)

Lierman (1976:106) points out that the final chapters of Deuteronomy offer both a characterisation of Moses and a prophetic foretelling of Israel's history'. Although the focus of Philo is on the philanthropy of Moses other than God's faithfulness attested in the course of Israel's past history, it is

14.For example, De Posteritate Caini 121 , 167 ; De plantatione 59 ; De sobrietate 10 ; De mutatione nominum 182 and De somniis 2:191.

15.LCL is an acronym of Loeb Classical Library. fair to say that he would stand square with the Tendenz of Second Temple Judaism in approaching their respective situations - at least because Philo regarded the Song as 'a prophetic text' (Waters 2006:70).

In summary, De virtutibus, along with De vita Mosis, helps us to understand how Jewish authors of the Second Temple period managed to map their respective situations into the topographical terrain of the Mosaic tradition in Deuteronomy 32.

\section{The writings of Josephus ${ }^{16}$}

Although Harrington (1973:63) views Antiquities 4:312-314 as a retelling of the Song, it is more likely that Deuteronomy 28 relates with Antiquities 4:312-314 (cf. Waters 2006:64-65). In Antiquities 4:305-308, Josephus dealt with the covenantal blessings and curses of Deuteronomy 27-28. However, Josephus did not employ the term $\delta i \alpha \theta \eta \dot{\kappa \eta}$ [covenant] by leaving the covenant renewal episode in Deuteronomy 29 untold when he dealt with Deuteronomy 29 in Antiquities 4:309-310. It is because, in Antiquities, Josephus primarily aimed at highlighting Moses' $\pi$ o $\lambda \iota \tau \varepsilon i ́ \alpha$ [constitution] (e.g. Ant 4:310). As with Philo's allusion of the Song in De virtutibus 72-75 promoting philanthropy, Josephus also understood Deuteronomy 28:58-68 not in terms of (covenantal) history, but as a 'prediction of future events' with a view to promoting the priestly aristocratic constitution (Waters 2006:65).

In summary, despite the fact that the 'pattern of history of Deuteronomy 32' can be found (Harrington 1973:63), it is fair to say that the Song may not be alluded to Antiquities $4: 312-314$.

\section{Sifre Deuteronomy}

Although Sifre Deuteronomy dates no earlier than the third century CE, it shows the Tendenz of Second Temple Judaism in approaching the present situation in terms of Israel's past history epitomised in the Song. For example, Piska 58, in which Deuteronomy 32:11 is alluded to, indicates how the rabbis regarded their words as 'both a continuation of and a participation in that originary event' (Fraade 1991:125):

And ye shall observe - this refers to study - to do - this refers to performance - all the statues - these are the interpretations - and the ordinances - these are the regulations - which I set before you this day (11:32) - let them be as precious to you as if you had received them from Mount Sinai today, let them be part of your discourse as frequently as if you had heard them today. (Piska 58) $)^{17}$

When it comes to such a 'dynamic interplay of prospection and retrospection' taken place in the engagement of the rabbis, Fraade (1991) attempts to make sense by saying that:

our experience of and actions in the present are determined to a large extent by our memories and retellings of the past and our anticipations, whether in hope or in fear, of the future. (p. 126)

16.Titus Flavius Josephus (37-100 CE) is a Jewish historian and hagiographer. His works give us a certain glimpse into the contours of Judaism in first-century period.

17.The translation of Sifre Deuteronomy is from Hammer (1986). 
According to Fraade, this is the case with the rabbis' dealings with Ha'azinu (the Song) in Piska 306. Piska 306 begins with alluding to Deuteronomy 32:1: Give ear, ye heavens, and I will speak (32:1). However, it seems that it has a negative bearing on such an invocation of heaven and earth:

R. Meir says: When Israel was meritorious, they gave witness against themselves, as it is said, And Joshua said unto the people, Ye are witnesses against yourselves (Josh. 24:22) ... After they had corrupted the heavens, as it is said ... God called the earth to witness against them, as it is said, Hear, O earth, behold, I will bring evil (upon this people) (Jer. 6:19). (Piska 306)

It is of interest to note that Piska 306 brings Israel's guilt to the fore by way of Israel's witnessing against themselves. In doing so, God's witnessing against Israel comes to the forefront. In Piska 306, God summons his witnesses from the earth to the ant: 'R. Simeon be Eleazar says: What a humiliation for this fellow to have to learn from the ant!' Then Piska 306 epitomises Israel's past history and provides various rabbinic interpretations of $\mathrm{Ha}^{\prime}$ azinu. Briefly put, Piska 306 begins with 'Israel's unworthiness' and ends with 'Israel's superiority' over the angels (Bell 1994:232; e.g. Piska 306 mentions the resurrection of the dead $\left.{ }^{18}\right)$ :

From the verses, Hear, O Israel, the Lord our God, the Lord is One (6:4), and, When the morning stars sang together, and all the sons of God shouted for joy (Job 38:7) - the morning stars are Israel, who are symbolized by the stars, as it is said, I will multiply thy seed as the stars of the heaven (Gen. 22:17); and all the sons of God shouted for joy refers to the ministering angels, as it is said, The sons of God came to present themselves before the Lord (Job 1:6). (Piska 306)

While Sifre Deuteronomy leaves the curses of Deuteronomy 27-28 untold, Piska 306 serves to heighten 'the element of comfort' (Hammer 1986:17). Fraade's (1991) observation is worth citing in full:

Scripture's notice of Moses' call to heaven and earth to hear his song is placed by the Sifre's commentary within a new, broader temporal framework; that is, within a larger historical progression of witnesses. This chain of witness is emblematic of the history of Israel's covenantal condition, beginning with her original innocence, continuing with her corruption and sense of abandonment by God, and ending with her future reconciliation with God. (p. 132)

In sum, in Sifre Deuteronomy, $\mathrm{Ha}^{\prime} a z i n u$ can give us a useful hint at the rationale of how and why Jewish authors of the Second Temple period patterned their respective situations according to the unfolding of Israel's past history. Hence, Fraade (1991:148, italics in the original) is correct in saying that:

[t]he contrast between God's seeming historical absence and the presence of the song within Israel ... reflects well the biblical rationale for the establishing of the song as witness in Deut. 31:16-21.

Piska 320, in which Deuteronomy 32:21 is alluded to, and Piskaot 342-343, in which Deuteronomy 32:43 is alluded to,

18.For example, the resurrection is also mentioned both in 2 Maccabees $7: 6$ (i.e. 2 Mac), in which Deuteronomy 32:36 is alluded to, and in 4 Maccabees 18:18-19 (i.e. $4 \mathrm{Mac})$, in which Deuteronomy 32:39 is alluded to. also point to the fact that Sifre Deuteronomy may adapt and adopt the Song in a form of 'future expansion'.

\section{Conclusion}

It was observed that the Song in Deuteronomy 32 is centred on God's faithfulness and righteousness in his dealings with Israel, without losing sight of the faithlessness and sin of Israel and their enemies. God's faithfulness and righteousness attested in the course of Israel's past history can be introduced in a didactic and timeless manner as 'a textual witness' for Israel's subsequent generations. Jewish authors of the Second Temple period appear to have regarded the Deuteronomic view of history in Deuteronomy 31-32 as a framework of history in their attempts to understand their respective situations. Nonetheless, it is also worth noting that the ways in which Jewish authors of the Second Temple period appropriated the Song and applied it to their respective situations are not monolithic. In other words, Jewish authors of the Second Temple period appear to have borne their own characteristics whenever they had the recourse to the Deuteronomic view of history in Deuteronomy 31-32. In CD 5:17, $1 \mathrm{QH}^{\mathrm{a}} 13: 10,27 ; 11: 31 ; 4: 13$ and $1 \mathrm{QM} \mathrm{12:11-12;} \mathrm{19:4,} \mathrm{the}$ Deuteronomic view of history in Deuteronomy 31-32 is intertwined with dualism or dualistic ways of thinking of the Qumran community. Tobit is depicted as the second Moses in Tobit 12-13, in which Israel's past history is summed up in terms of the Deuteronomic view of history in Deuteronomy 31-32. In doing so, the hope of Israel's future is interlaced with Israel's exilic present. The author of T. Moses introduced Taxo the Levite as the martyred righteous in provoking God's vengeance in terms that the Song should be understood as a 'prediction of the future' (Harrington 1973:66). In a similar vein, Sifre Deuteronomy also clearly shows that the rabbis appear to have regarded their situation as both the continuation and the participation of the Deuteronomic view of history in Deuteronomy 31-32. In Piska 306, by highlighting 'the element of comfort' (Hammer 1986:17), the Song serves to epitomise Israel's history, which begins with Israel's unworthiness and ends with Israel's superiority over the angels (Bell 1994:232). In De virtutibus 73 and 75, however, Philo did not understand the Song as referring to a 'prediction of the future'. Instead,

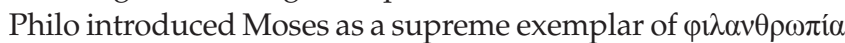
[philanthropy]. Notwithstanding this, De virtutibus shows the tendency to map the present situation into the topographical terrain of the Mosaic tradition in Deuteronomy 32 in the Second Temple period. All in all, it is made clear that, by having the recourse to the Song, Jewish authors of the Second Temple period attempted to overcome their despondency in their respective situations resulting from the absence of the covenant God. Hence, we can assume that the Deuteronomic view of history in Deuteronomy 31-32 furnishes a framework of history during the Second Temple period.

\section{Acknowledgements Competing interests}

The authors declare that they have no financial or personal relationships that may have inappropriately influenced them in writing this article. 


\section{Authors' contributions}

All authors contributed equally to the writing of this article.

\section{Funding information}

A.G-F., Old Testament Studies, Faculty of Theology and Religion, University of Pretoria, provided funding for this study.

\section{References}

Abasciano, B.J., 2005, Paul's use of the Old Testament in Romans 9:1-9: An intertextual and theological exegesis, The Library of New Testament Studies 301, T \& T Clark, London.

Bauckham, R., 2006, 'Tobit as a parable for the exiles of Northern Israel', in M. Bredin (ed.), Studies in the book of Tobit: A multidisciplinary approach, pp. 140-164, T \& T Clark, London.

Bell, R.H., 1994, Provoked to jealousy, Wissenschaftliche Untersuchungen zum Neuen Testament 2 63, Mohr Siebeck, Tübingen.

Braulik, G., 1994, The theology of Deuteronomy: Collected essays of Gerog Braulik transl. U. Lindbald, BIBAL Press, Richland Hills, TX.

Britt, B.M., 2004, Rewriting Moses: The narrative eclipse of the text, Journal for the Study of the Old Testament Supplement Series 402, T \& T Clark International, London.

Craigie, P.C., 1976, The book of Deuteronomy, Eerdmans, Grand Rapids, MI.

Crawford, S.W., 2005, 'Reading Deuteronomy in the Second Temple period', in K. de Troyer \& A. Lange (eds.), Reading the present in the Qumran library: The perception of the contemporary by means of scriptural interpretations, pp. 127-140, Society of Biblical Literature Symposium Series 30, Society of Biblical pp. 127-140, Society of
Literature, Atlanta, GA.

Crowe, B.D., 2012, The obedient son: Deuteronomy and Christology in the gospel of Matthew, Beihefte zur Zeitschrift für die neutestamentliche Wissenschaft und die Kunde der älteren Kirche 188, Walter de Gruyter, Berlin.

Fitzmyer, J.A., 2003, Tobit, Walter de Gruyter, Berlin.

Fraade, S.D., 1991, From tradition to commentary: Torah and its interpretation in the Midrash Sifre to Deuteronomy, SUNY series in Judaica 73, SUNY Press, Albany, NY

García Martínez, F. \& Tigchelaar, E., 1997-1998, The Dead Sea scrolls: Study edition, Brill, Leiden.

Gathercole, S.J., 2002, Where is boasting? Early Jewish soteriology and Paul's response in Romans 1-5, Eerdmans, Grand Rapids, MI.

Hammer, R., 1986, Sifre: A Tannaitic commentary on the Book of Deuteronomy, Yale Judaica series 24, Yale University Press, New Haven, CT.

Harrington, D.J., 1973, 'Interpreting Israel's history: The Testament of Moses as a rewriting of Deut 31-34', in G. Nickelsburg (ed.), Studies on the Testament of Moses: Seminar papers, pp. 59-68, Society of Biblical Literature, Cambridge, MA.
Hays, R.B., 1989, Echoes of scripture in the letters of Paul, Yale University Press, New Haven, CT.

Henderson, R., 2014, Second Temple songs of Zion: A literary and generic analysis of the Apostrophe to Zion (11QPS ${ }^{a}$ XXII 1-15), Tobit 13:9-18 and 1 Baruch 4:305:9, Deuterocanonical and Cognate Literature Studies 17, Walter de Gruyter, Berlin.

House, P.R., 1990, The unity of the twelve, Journal for the Study of the Old Testament Supplement Series 77, Sheffield Academic Press, Sheffield.

Lange, A., 1997, 'The Essene position on magic and divination', in M. Bernstein F.G. Martínez \& J. Kampen (eds.), Legan texts and legal issues: Proceedings of the Second Meeting of the International Organization for Qumran Studies, published in Honour of Joseph M. Baumgarten, pp. 377-436, Brill, Leiden.

Lange, A., 2012, 'The textual history of the Book of Jeremiah in light of its allusions and implicit quotations in the Qumran Hodayot', in J. Penner, K. Penner \& C. Wassen (eds.), Prayer and poetry in the Dead Sea Scrolls and related literature: Essays in Honor of Eileen Schuller on the occasion of her 65th birthday, pp. 251-284, Brill, Leiden.

Licht, J., 1961, 'Taxo, or the Apocalyptic doctrine of vengeance', Journal of Jewish Studies 12, 95-103. https://doi.org/10.18647/470/JJS-1961

Lierman, J., 1976, The New Testament Moses: Christian perceptions of Moses and Israel in the setting of Jewish religion, Wissenschaftliche Untersuchungen zum Neuen Testament 173, Mohr Siebeck, Tübingen.

Lundbom, J.R., 2013, Deuteronomy: A commentary, Eerdmans, Grand Rapids, MI.

Lincicum, D., 2010, Paul and the early Jewish encounter with Deuteronomy, Wissenschaftliche Untersuchungen zum Neuen Testament 2 284, Mohr Siebeck, Tübingen.

Mayes, A.D.H., 1981, Deuteronomy, Eerdmans, Grand Rapids, MI.

Moore, C.A., 1996, Tobit: A new translation with introduction and commentary, Doubleday, New York, NY.

Morland, K.A., 1995, The rhetoric of curse in Galatians: Paul confronts another Gospel, Scholars Press, Atlanta, GA.

Nelson, R.D., 2004, Deuteronomy: A commentary. Westminster John Knox Press, Louisville, KY

Priest, J., 1983, 'Testament of Moses', in J.H. Charlesworth (ed.), The Old Testament Pseudepigrapha, vol 1, pp. 919-934, Doubleday, New York, NY.

Thiessen, M., 2004, 'The form and function of the Song of Moses (Deuteronomy 32:1-43)', Journal of Biblical Literature 123(3), 401-424. https://doi.org/ $10.2307 / 3268040$

Tromp, J., 1993, The assumption of Moses: A critical edition with commentary, Studia in Veteris Testamenti Pseudepigrapha 10, Brill, Leiden.

Uusimäki, E., 2016, Turning proverbs towards Torah: An analysis of 4Q525, Studies on the Texts of the Desert of Judah 117, Brill, Leiden.

Waters, G.P., 2006, The end of Deuteronomy in the epistle of Paul, Wissenschaftliche Untersuchungen zum Neuen Testament 2 221, Mohr Siebeck, Tübingen.

Weitzman, S., 1994, 'Lessons from the dying: The role of Deuteronomy 32 in its narrative setting', Harvard Theological Review 87(4), 377-393.

Weitzman, S., 1997, Song and story in Biblical narrative: The history of a literary convention in ancient Israel, Indiana University Press, Bloomington, IN. 